\title{
PENGARUH PELAKSANAAN PRENATAL GENTLE YOGA TERHADAP KECEMASAN MENJELANG PERSALINAN PADA IBU HAMIL PRIMIGRAVIDA TRIMESTER III DI KLINIK BIDAN KITA KLATEN
}

\author{
Ritsma Zunira Aryani, Rohmi Handayani, Dewi Susilowati \\ Kementerian Kesehatan Politeknik Kesehatan Surakarta Jurusan Kebidanan \\ Diterima : 13 Agustus 2018, Disetujui : 27 Agustus 2018
}

\begin{abstract}
Background: Prolonged anxiety at labor may result in abnormal labor and unfavorable effects on the fetus. To break the chain of anxiety can be done with prenatal gentle yoga, because in the prenatal gentle yoga there are pose that can make the pregnant woman relax.To know the characteristics of respondents, to know the average anxietyscore before and after prenatal gentle yoga and to know the impact of prenatal gentle yoga implementation on the anxiety before the delivery of primigravida third trimester pregnant women at Bidan Kita Clinic, Klaten.The research used quasy experiment with one group pretest-posttest approach. Method:The sampling technique used is total sampling, obtained the number of samples of 32 trimester pregnant women III who follow prenatal gentle yoga in the first time. Correlation analysis technique used Paired T Test. From 32 respondents, showed that the majority (97\%) of respondents were 20 35 years old with higher education background (50\%) and worked as private (37\%), the average anxiety score before prenatal gentle yoga was 27.4375 and the average anxiety score after prenatal gentle yoga decreased to 23.1563. The anxiety degradation score ahead of delivery to the respondents was 4.2812. Result: The result of data normality test, distribution of data in this research is normal distribution hence correlation test used Paired T test with value p value is 0.000 ( $p<0.05$ ). There is a significant decrease in respondents' anxiety scores. Conclusion: There is a strong impact between the prenatal gentle yoga exercise on theanxiety winning of labor in pregnant primigravida in third trimester at Bidan Kita Clinic, Klaten.
\end{abstract}

Keywords: Pregnancy, Prenatal Gentle Yoga, Pregnancy Anxiety

PENDAHULUAN

Kehamilan merupakan suatu proses yang berkesinambungan terdiri dari ovulasi pelepasan sel telur, migrasi spermatozoa dan ovum, konsepsi dan pertumbuhan zigot, nidasi (implantasi) pada uterus, pembentukan plasenta, dan tumbuh kembang hasil konsepsi sampai aterm (Manuaba, 2010). Sepanjang kehamilannya ibu hamil harus melalui berbagai tingkat ketidaknyamanan terutama pada trimester III seperti dispnea, insomnia, gingivitis dan epulis,sering buang air kecil, tekanan dan ketidaknyamanan pada perineum, nyeri punggung, konstipasi, varises, mudah lelah, kontraksi braxton hicks, kram kaki, edema pergelangan kaki dan perubahan mood serta peningkatan kecemasan (Bobak, 2005).

Trauma, stres atau cemas dapat memunculkan gejala fisik seperti letih, lesu, mudah marah, gelisah, pening, mual dan malas. Perubahan yang terjadi pada 
fisik mempengaruhi aspek psikologis dan sebaliknya, sehingga mudah bagi ibu hamil untuk mengalami trauma (Kuswandi, 2013). Perasaan atau trauma yang dirasakan ibu hamil dapat dirasakan oleh janin, yaitu dengan menunjukkan reaksi terhadap stimulasi yang berasal dari luar tubuh ibunya danmenyebabkan persalinan yang traumatik (Kuswandi, 2013). Hal ini sejalan dengan penelitian Misri (2010) bahwa depresi pada kehamilan trimestermenyumbang $13 \%$ sampai $22 \%$ kejadian stres postpartum pada bulan ketiga dan keenam.

Menurut data SDKI tahun 2017, menunjukan angka kematian ibu sebanyak 1712 pada tahun 2017. Dimana salah satu penyebab kematian ibu adalah adanya komplikasi pada saat persalinan ataupun pada saat nifas. Salah satu penyebab dari komplikasi.saat persalinan yakni adanya rasa cemas/stress yang tidak tertangani dengan baik saat hamil (Saifuddin, 2010). Hormon stress yang dihasilkan secara berlebihan pada wanita hamil juga dapat mengganggu suplai darah ke janin. Akibatnya risiko kemungkinan anak dilahirkan dengan berat badan lahir rendah (BBLR), ukuran kepalanya kecil (microsomia), perkembangan sarafnya tidak seimbang, lahir prematur, melemahnya sistem kekebalan tubuh bayi serta gangguan emosi bahkan kematian bayi (Aprilia, 2010).

Oleh karena itu dalam mempersiapkan kehamilan, ibu hamil tidak boleh memperhatikan kesehatan fisik saja tetapi juga harus menjaga kesehatan mental dan spiritualnya (Kuswandi, 2013). Alternatif terapi yang dibutuhkan dalam kehamilan adalah pemijatan dan terapi energi

Seperti massage, acupressure, therapeutic touch dan healing touch dan mind body healing seperti imagery, meditasil yoga, berdoa, refleksi biofeedback (Perry et. al, 2010).

Berdasarkan study pendahuluan yang dilakukan peneliti pada tanggal 23 Desember 2017 di Klinik Bidan Kita Klaten dari jumlah 10 orang ibu hamil trimester III terdapat 6 orang ibu hamil primigravida. Pada saat dilakukan pengkajian kepada ibu hamil primigravida dengan wawancara dan pengisian kuesioner menggunakan instrumen ASP (Anxiety Scale forPregnancy) didapatkan hasil 4 orang ibu hamil primigravida trimester III yang masuk dalam kategori cemas sedang dan belum pernah mengikuti kelas prenatal gentle yoga sebelumnya dan 2 orang ibu hamil primigravida trimesteryang masuk dalam kategori ringan dan sudah 2 kali mengikuti kelas prenatal gentle yoga.Berdasarkan data dan fenomena yang ada maka penulis tertarik untuk melakukan penelitian pengaruh prenatal gentle yoga terhadap kecemasan menjelang persalinan pada ibu primigravida trimester III di Klinik Bidan Kita Klaten.

\section{METODE PENELITIAN}

Penelitian ini merupakan jenis penelitian Quasi-eksperimental design dengan racangan one group pretest posttest design. Observasi dilakukan 2 kaliyaitu sebelum perlakuan dan sesudah perlakuan. Observasi yang dilakukan sebelum perlakuan disebut pretest dan observasi sesudah perlakuan disebut posttest.

Penelitian dilakukan di Klinik Bidan Kita. Adapun waktu penelitian dilaksanakan mulai bulan Desember 2017 sampai dengan bulan Juni 2018. Populasi adalah wilayah generalisasi yang terdiri atas objek atau subjek yang mempunyai 
kualitas dan karakteristik tertentu yang ditetapkan oleh peneliti untuk dipelajari dan ditarik kesimpulan (Notoatmojo, 2012). Populasi dalam penelitian ini adalah ibu hamil primigravida trimester III yang mengikuti kelas prenatal gentle yoga sebanyak 32 ibu hamil. Pengambilan sampel menggunakan Total Sampling dengan metode Accidental Sampling .

Instrumen dalam penelitian ini yaitu lembar observasi Anxiety Scale forPregnant (ASP) yaitu untuk mengetahuiskor kecemasan yang dialami oleh responden sebelum dan sesudah mengikuti kelas prenatal gentle yoga.

Pada penelitin ini menggunakan uji Shapiro-Wilk untuk mengetahui kenormalan data dengan hasil data berdistribusi normal sehingga analisa data dilakukan menggunakan uji statistik paired t-test. Pengujiandilakukan dengan bantuan program SPSS 21.0 for Windows.

\section{HASIL PENELITIAN}

1. Analisis Univariat

Hasil Pengukuran Skor

Kecemasan sebelum dan sesudah Melakukan Prenatal Gentle Yoga

Tabel 1. Skor Kecemasan Rata-Rata Responden Sebelum dan Sesudah Melakukan Prenatal Gentle Yoga

\begin{tabular}{lll}
\hline & Sebelum & Sesudah \\
\hline Mean & 27.4375 & 23.1563 \\
Std.Dev & 4.31006 & 3.75980 \\
Asym.Sig & 0.469 & 0.166 \\
\hline
\end{tabular}

Berdasarkan tabel 1 dapat diketahui bahwa sebelum melakukan prenatal gentleyoga skor rata-rata kecemasan responden yaitu 27.4375. Dengan nilai persebarannya adalah 4.31006.Sedangkan setelah melakukan prenatal gentleyoga skor rata-rata kecemasan responden yaitu 23.1563. Dengan nilai persebarannya adalah 3.75980. Maka apabila dilihat dari skor rata-rata kecemasan sebelum dan sesudah dapat diketahui mengalami penurunan skor sebesar 4.2812.

\section{Analisis Bivariat}

Dari data yang diperoleh pada hasil pengukuran skor kecemasan rata-rata sebelum dan sesudah melakukan Prenatal Gentle Yoga, kemudian dilakukan uji hipotesis dengan tingkat kepercayaan $95 \%$ dan taraf kesalahan 5\% menggunakan software SPSS 21.0untuk mengetahui pengaruh Pelaksanaan Prenatal Gentle Yoga terhadap Kecemasan Menjelang Persalinan Pada Ibu Hamil Primigravida Trimester III.

Tabel 2. Selisih Hasil Pengaruh Pelaksanaan Prenatal Gentle Yoga Terhadap Kecemasan Menjelang Persalinan pada Ibu Hamil Primigravida Trimester III di Klinik Bidan Kita Klaten

\begin{tabular}{lc}
\hline \multicolumn{1}{c}{ Sebelum - Sesudah } & Jumlah \\
Prenatal Gentle Yoga & \\
\hline Negative Ranks & 30 \\
Positive Ranks & 0 \\
Tiles & 2 \\
Total & 32 \\
\hline
\end{tabular}

Bedasarkan tabel 2 menunjukkan bahwa responden yang mengalami penurunan skor kecemasan sebanyak 30 orang, responden dengan skor kecemasan tetap sebanyak 2 orang dan tidak ada responden yang mengalami peningkatan skor kecemasan.

Tabel 3. Hasil Pengaruh Pelaksanaan Prenatal Gentle Yoga Terhadap 
Kecemasan Menjelang Persalinan pada Ibu Hamil Primigravida Trimester III di Klinik Bidan Kita Klaten

\begin{tabular}{cc}
\hline $\begin{array}{c}\text { Pre test - post } \\
\text { test }\end{array}$ & Hasil \\
\hline Sig (2-tailed) & 0.000 \\
\hline Berdasarkan & tabel
\end{tabular}

menunjukkan bahwa hasil uji hipotesis menunjukkan nilai sig $(-2$ tailed $)=$ 0,000 sehingga $0,000<0,05$ berarti ada pengaruh yang signifikan sebelum dan sesudah melakukan prenatal gentle yoga terhadap penurunan skor rata-rata kecemasan.

\section{PEMBAHASAN}

Pada penelitian ini menunjukkan bahwa karakteristik ibu primigravida trimester III yang mengikuti kelas prenatal gentle yoga berdasarkan usia ibu sebagian besar ibu berusia 20-35 tahun yaitu sebanyak $31(97 \%)$ responden. Hal tersebut sesuai dengan Depkes RI (2009) dan Manuaba (2010) yang menyatakan bahwa usia yang matang untuk reproduksi sehat dari segi fisik dan psikis adalah usia dalam rentang 20-35 tahun. Karakteristik responden dari segi pendidikan menunjukkan separuh dari responden memiliki latar belakang pendidikan perguruan tinggi yaitu sebanyak $16(50 \%)$ responden dan sisa lainnya berpendidikan dasar $(9.4 \%)$ serta pendidikan menengah (40.6\%). Menurut Pieter (2010), tingkat pendidikan berpengaruh pada kemampuan berfikir rasional dan pola cepat dalam menguraikan masalah yang baru yang dapat memicu kecemasan pada seseorang.

Data distribusi frekuensi karakteristik pekerjaan responden menunjukkan bahwa sebagian besar responden adalah ibu bekerja, baik bekerja sebagai PNS 6 (18.8\%), swasta 12(37.5\%) dan wiraswasta $8(25 \%)$. Pekerjaan dapat menggambarkan status ekonomi seseorang, status ekonomi yang rendah akan menyebabkan kurangnya pengetahuan yang didapat oleh ibu dan persiapan ibu dalam mempersiapkan persalinan kelak (Pieter,2010). Hal tersebut sejalan dengan penelitian yang dilakukan oleh Chalimah (2013) yang menunjukkan bahwa $60 \%$ dari 55 responden yang memiliki status ekonomi tinggi diantaranya mengalami kecemasan ringan sebanyak 11 responden,kecemasan sedang 18 responden dan 4 responden mengalami kecemasan berat.

Penelitian mengenai pelaksanaan prenatal gentle yoga di Klinik Bidan Kita menunjukkan bahwa ibu primigravida trimester III yang menjadi responden sebelum melakukan prenatal gentle yoga memiliki skorkecemasan rata-rata 27.4375 dimana skor tersebut jika dikategorikan masuk dalam kategori kecemasan sedang. Hal tersebut sejalan dengan teori Bobak (2005) bahwa seorang ibu hamiltrimester III akan mengalami kecemasan akibat adanya perubahan fisik dan psikologis. Serta didukung dengan penelitian Rosyidah (2010), bahwa tingkat kecemasan $\mathrm{ibu}$ hamil primigravida trimester III dalam menghadapi persalinan di BPS Ny. Roidah, SST, M.Kes Desa Dlanggu, Mojokerto sebanyak 13 orang (65\%) mengalami kecemasan sedang.

Menurut hasil wawancara kepada responden mengenai kecemasan yang terjadi, kecemasan pada ibu timbuldikarenakan memikirkan apakah dirinya mampu untuk melakukan persalinan, bagaimana keadaan bayinya nanti, dan apakah dirinya mampu merawat bayinya. Sesuai dengan teori Pieter (2010) kehamilan primigravida sedang mengalami sesuatu yang belum pernah dialaminya dan pengalaman tersebut 
membuat ibu merasa tidak nyaman. Kehamilan pertama merupakan fase baru dalam perkebangan hidupnya yang penuh teka -teki, kebahagian dan perghargaan tertentu. Ia merasakan ketidaknyamanan fisik, merasakan keletihan, merasakan cemas akan kesejahteraan atau keadaan janin yang dikandung, juga mersa takut sakit pada pesalinan nanti. Calon ibu lebih menjadi introspektif dan mulai banyak memikirkan dan mencemaskan persalinan, kelahiran, dan bayinya. Kecemasan menghadapi persalinan membuat ibu mulai protektif terhadap bayi yang sedang berkembang dan mencoba menghindari hal - hal yang dapat mengganggu kesejahteraannya (Hamilton,1995).

Skor rata-rata kecemasan responden setelah mengikuti prenatalgentle yoga sebanyak 3 kali turun menjadi 23.1563 dengan nilai penurunan skor sebanyak 4.2812 skor. Hal ini sesuai dengan hasil penelitian yang dilakukan oleh Dian (2015), bahwa efek yoga terhadap kecemasan ibu hamil menunjukkan penurunan kecemasan yang signifikan yakni dengan nilai $\mathrm{p}$ value 0.003. Penurunan kecemasan yang dipengaruhi oleh prenatal gentle yoga ini akibat dari rasanyaman yang dirasakan ibu hamil selama mengikuti kelas, sehingga akan membuat otot-otot rileks, pikiran tenang, dan meningkatkan kemampuan berkonsentrasi.

Secara teoritis kecemasan akan turun jika individu mengalami relaksasi pada tubuhnya (Spielberger, 1966). Latihan prenatal gentle yoga adalah sebuah treatmen fisik yang ternyata juga dapat memberikan efek psikologis karena memberikan efek relaksasi pada tubuh seseorang dan mempengaruhi beberapa aspek psikologis padaseseorang yang melakukannya dikatakan dapat membantu menurunkan kecemasan (Aprilia, 2014).
Unsur pada prenatal gentle yoga yang dapat membantu menurunkan kecemasan adalah pada bagian relaksasi dan meditasi. Menurut Babbar \& Shyken (2016), yoga adalah latihan pikiran dantubuh yang mencakup latihan peregangan dan postur tubuh (asana) yang dikombinasikan dengan pernapasan dalam dan meditasi (pranayama). Yoga membutuhkan koordinasi gerakan tubuh dan napas dengan fokus pada kesadaran diri.

Prenatal gentle yoga dapat
membantu mengendalikan pikiran, keinginan, dan reaksi terhadap stress. Prenatal gentleyoga ini terdiri dari tiga beberapabagian, antara lain relaksasi, mengatur postur, dan olah napas. Dalam prenatalgentle yoga di Klinik Bidan Kita,instruktur mendeskripsikan aba-aba setiap gerakan, dilakukan dengan suara yang lembut, kalimat yang mudah dipahami, dan diiringi oleh musik dengan irama yang juga lembut. Pada saat sesi relaksasi, ibu hamil diminta untuk berbaring dan memejamkan mata, kemudian mengikuti imaginasi dan napas dalam yang diarahkan oleh instruktur. Menurut Jerath et al (2009), pernapasan dalam dapat mengaktifkan sistem saraf parasimpatis, terutama dengan meregangkan jaringan paru dan saraf vegal. Hal ini menyebabkan respon fisiologis ditandai dengan penurunan denyut jantung, tekanan darah, tingkat metabolisme, dan konsumsi oksigen. Pernapasan dalam juga meningkatkan neuroplastisitas, yang didefinisikan sebagai reorganisasi jalur saraf sebagai respon adaptif. Secara umum orang yang melakukan yoga akan mendapatkan banyak manfaat, salah satunya adalah menurunkan kecemasan pada ibu hamil. Dari kedua data skor kecemasan 
responden sebelum dan sesudah mengikuti kelas prenatal gentle yoga, dilakukan uji Paired $T$ Test untuk mengetahui signifikansi pengaruh prenatal gentle yoga terhadap kecemasan menjelang persalinan pada ibu primigravida trimester III. Berdasarkan hasil uji tersebut, diperolehhasil nilai signifikansi $p$ value sebesar 0,000. Artinya, bahwa nilai $p$ value $(0,000)<0,05$ maka Ho ditolak. Hal ini menunjukkan bahwa hipotesis penelitian ini diterima yaitu ada pengaruh prenatal gentle yoga terhadap kecemasan ibu primigravida trimesterdi Klinik Bidan Kita Klaten. Keseluruhan dari penelitian ini menunjukkan bahwa prenatal gentleyoga dapat membantu ibu hamil dalam mengatasi keluhan selama trimester III, khususnya keluhan tentang kecemasan menjelang persalinan. Menurut Aprilia (2014) bahkan seorang ibu hamil yang memulai melakukan yoga pada trimester II, akan menunjukkan penurunan yang sangat signifikan pada parameter dasar kecemasannya.

\section{KESIMPULAN DAN SARAN}

Berdasarkan hasil penelitian dapat disimpulkan bahwa ada pengaruh yang signifikan sebelum dan sesudah dilakukan prenatal gentle yoga dengan nilai sig ( -2 tailed $)=0,000$. Bahwa $0,000<0,05$ yang menunjukkan ada pengaruh pelaksanaan prenatal gentle yoga terhadap penurunan nyeri punggung. Diharapkan hasil penelitian ini dapat digunakan oleh bidan dalam memberikan asuhan kebidanan pada ibu hamil yang mengalami kecemasan menjelang persalinan sebagai salah satu bentuk pengobatan non farmakologi. Selain itu, diharapkan peneliti selanjutnya dapat mengembangkan penelitian ini dengan melakukan penelitian yang lain mengenai manfaat prenatal gentle yoga seperti optimalisasi posisi janin.

\section{DAFTAR RUJUKAN}

Aprillia,Yesie. (2010). Hipnostetri, Rileks, nyaman, dan aman saathamil danmelahirkan. Jakarta :Gagas Media

Aprilia,Yesie. (2014). Gentle Birth Balance. Mizan: Bandung

Babbar, Shilpa, MD, Shyken, Jaye, MD. (2016). Yoga in Pregnancy Clinical Obstetrics and Gynecology. Volume 00.

Bobak, I.M., Lowdermilk, D. \& Jensen, M.D. (2005). Keperawatan Maternitas Alih bahasa.

Chalimah Siti, dkk. (2013) Analisis Faktor - Faktor Yang Mempengaruhi Kecemasan Ibu Hamil Menghadapi Persalinan di Rumah Bersalin Mandiri Rahayu Semarang.Semarang : Universitas Ngudiwaluyo Ungaran.

Hamilton, PM. 1995. Dasar-dasar keperawatan Maternitas, Edisi 6. Jakarta :EGC 